\title{
Effects of sex, host-plant deprivation and presence of conspecific immatures on the cannibalistic behavior of wild Ascia monuste orseis (Godart) (Lepidoptera, Pieridae)
}

\author{
Alessandra F. K. Santana ${ }^{1}$, Rosana C. Zago ${ }^{1}$ \& Fernando S. Zucoloto ${ }^{1}$ \\ ${ }^{1}$ Department of Biology, Faculdade de Filosofia, Ciências e Letras de Ribeirão Preto, Universidade de São Paulo, Av. Bandeirantes, 3900, Monte \\ Alegre, 14041-900 Ribeirão Preto-SP, Brazil. zucoloto@ffclrp.usp.br

\begin{abstract}
Effects of sex, host-plant deprivation and presence of conspecific immatures on the cannibalistic behavior of wild Ascia monuste orseis (Godart) (Lepidoptera, Pieridae). The specialist cabbage caterpillar Ascia monuste orseis (Lepidoptera, Pieridae) feeds on plants of the Brassicaceae family, but may eventually ingest conspecific eggs and larvae during the larval stage. The present study examines feeding behavior of $4^{\text {th }}$ and $5^{\text {th }}$ instar cabbage caterpillars in relation to sex, host-plant deprivation and presence of conspecifics. We recorded number of egg ingested per larvae, developmental indices and duration of feeding, exploratory and resting behavior. Kale deprived caterpillars presented high rates of cannibalism, development delay and decreased fecundity. Cannibalism rates were not influenced by the sex of the larvae. In general, the presence of conspecific eggs did not interfere with the frequency and duration of the categorical behavioral events. We conclude that food availability is a strong factor influencing the extent to which A. monuste orseis caterpillars cannibalize.
\end{abstract}

KEYWORDS. Brassicaceae; cannibalism; feeding; herbivorous insects.

RESUMO. Influência do sexo, da privação de plantas hospedeiras e da presença de imaturos coespecíficos no comportamento canibal de Ascia monuste orseis (Godart) (Lepidoptera, Pieridae) selvagens. A curuquerê-da-couve, A. monuste orseis (Lepidoptera, Pieridae), alimenta-se de plantas da família Brassicaceae, mas ingere ovos e larvas coespecíficos, quando disponíveis, durante a fase larval. O comportamento alimentar de lagartas de $4^{\circ}$ e $5^{\circ}$ ínstares foi estudado em relação ao sexo e à privação de alimento afetando as taxas de canibalismo, e a presença de ovos coespecíficos afetando o comportamento alimentar. Foram mensurados: número de ovos ingeridos/larva, tempo de desenvolvimento, tamanho do adulto, fecundidade e duração dos comportamentos de alimentação, exploração e repouso. Lagartas privadas de couve apresentaram altas taxas de canibalismo, atraso no desenvolvimento e diminuição do número de oócitos. As taxas de canibalismo não foram influenciadas pelo sexo da larva. De um modo geral, a presença de ovos coespecíficos não interferiu na duração e na freqüência dos comportamentos de repouso, exploratório e alimentar. Concluímos que a disponibilidade de alimento é um fator que influencia fortemente na extensão do canibalismo por lagartas de A. monuste orseis.

PALAVRAS-CHAVE. Alimentação; Brassicaceae; canibalismo; insetos herbívoros.

During certain life stages or periods of food shortage, some natural insect populations have been shown to use conspecific tissues as a major source of nutrition (Joyner \& Gould 1985). Cannibalism plays an important role in the biology of many insect species and may influence population structure, life history, competition for resources and behavior (Polis 1981). The larvae of several Lepidoptera species are known to feed on conspecific eggs, larvae and sometimes even pupae (Whitman et al. 1994) in natural conditions. Evidence suggests that cannibalism increases as the abundance or nutritional quality of primary food resources decrease (Fox 1975; Polis 1981; Agarwala \& Dixon 1992).

The cabbage butterfly Ascia monuste orseis (Godart, 1819) (Lepidoptera, Pieridae) is a specialist on plants of the Brassicaceae family. A single laying of these females may be as large as 60 eggs, which are usually distributed in many plants in nature (Catta-Preta \& Zucoloto 2003). However, females may oviposit on plants which already have conspecifics (eggs and/or caterpillars) (Barros-Bellanda \& Zucoloto 2005) leading to the occurrence of egg cannibalism. Egg cannibalism is observed in both field and laboratory and it may also occur in the presence of abundant food (BarrosBellanda \& Zucoloto 2005). The first-hatched caterpillars may ingest whole eggs from the same clutch or from other ones laid close together on the same leaf, and older ones could ingest both eggs and newly-hatched larvae found on the same plant (Barros-Bellanda \& Zucoloto 2001).

Most lepidopteran species obtain nutrients for egg provisioning during the larval stage and may supplement with nectar feeding as adults (Boggs 1997; Boggs \& Freeman 2005). The lack of substantial amounts of amino acids in nectar (Slansky \& Scriber 1985), in addition to the high protein demand of egg provisioning, suggests that females rely on their larval diet to obtain this protein supply (Telang et al. 2001). In Lepidoptera, females tend to weight more than males, a feature that has been attributed to the role of producing eggs (Slansky \& Scriber 1985). But, do immature females increase the ingestion of the host comparable to immature males? Alternatively, do differences between the sexes arise after ingestion? 
Some of the temporal analysis of feeding behavior in insects had been focused on Locusta migratoria (Simpson 1982, 1995), whose feeding occurs in bouts that are clearly separated by periods of resting on a perch away from the food (Simpson 1982). Previous research on caterpillars, i.e. Manduca sexta (Reynolds et al. 1986; Bernays \& Woods 2000), Helicoverpa armigera (Raubenheimer \& Barton-Browne 2000) and Bombyx mori caterpillars (Nagata \& Nagasawa 2006) have shown that the pattern of feeding (i.e. the frequency and duration of meals) varies across foods types (Reynolds et al. 1986; Timmins et al. 1988; Bernays \& Singer 1998) and can provide information about the insect's physiological responses to food. For instance, the phagostimulatory power of food influences both the probability of initiating feeding and the duration of the meal (Simpson \& Raubenheimer 2000). The duration of the interval until the next meal reflects the size and nutrient content of the previous meal (Colasurdo et al. 2007).

In this context, the present work aimed at testing: (1) whether males and females of $A$. monuste orseis caterpillars differ in relation to their cannibalism rates (due to the great protein investment of females during the production of oocytes, it might be expected that females ingest more eggs than males when they have the chance), (2) whether caterpillars with different nutritional quality foods differ in its performance and in its cannibalism rates (it is suspected that deprivation of the vegetable source causes an increase in the rate of cannibalism), and (3) whether the presence of conspecific eggs as food affects feeding behavior of $A$. monuste orseis. Egg cannibalism probably changes the proteins and amino acids quality and proportion on the diet, compared to diets of non-cannibal individuals, and these physiological differences may reflect on the larvae behavior.

\section{MATERIAL AND METHODS}

Study System. Eggs of A. monuste orseis were collected from kale leaves (Brassica oleracea var. acephala) in a pesticide free experimental garden in the University campus $\left(21^{\circ} 05^{\prime} \mathrm{S}, 47^{\circ} 50^{\prime} \mathrm{W}\right)$, Ribeirão Preto County, SP State, Brazil. Seven newly hatched caterpillars (NHC) were placed in plastic boxes $(10 \times 10 \times 4 \mathrm{~cm})$ lined with paper towel (Felipe \& Zucoloto 1993). Food was provided ad libitum and replaced daily. Experiments with individual larvae were conducted in glass containers ( $5.5 \mathrm{~cm}$ diameter, $7 \mathrm{~cm}$ height) covered with tulle. Both containers were kept in an incubator at $29 \pm 2^{\circ} \mathrm{C}$; with a fluorescent lamp (400 lux) on 10:14 (L:D) cycle and $75 \%$ humidity (Felipe \& Zucoloto 1993). Fourth and fifth instar caterpillars were used in the experiments because (1) oldest caterpillars exhibit greater power of predation due to the greater mobility and the physical structure of its jaws (Zago-Braga \& Zucoloto 2004), (2) in these instars, the caterpillars tend to feed solitariously, similar condition to the present experiments and (3) food deprivation of 24 hours in the $4^{\text {th }}$ instar - required condition for the experiment realization - is not lethal to larvae (Barros-Bellanda \& Zucoloto 2003).
Sex differences on conspecific ingestion. A. monuste orseis caterpillars were fed with kale ad libitum up to the treatment application. Treatments consisted of placing newly molted $5^{\text {th }}$ instar caterpillars individually in the glass containers described above and offering ad libitum kale to the control group while the experimental group were provided also with $10 \mathrm{NHC}(\mathrm{n}=25$ per treatment). After 24 hours, all remaining $1^{\text {st }}$ instar caterpillars of the experimental group were removed. Both groups received kale ad libitum during the larval stage.

Because we could not assign sex to the larvae, cannibalism rates were taken for all larvae and sex assignment was made after adult emergence. The parameters analyzed were cannibalism rate and adult weight. Cannibalism rate was measured as the total number of caterpillars consumed, counted at the end of the experimental period. After emergence, adults of each sex $(n=10$ per sex $)$ were separated for the determination of dry weight. For the analysis we used the $t$-test, with $\alpha=0.05$.

Effect of different nutritional quality foods on performance. To test whether kale satiation influence the propensity to cannibalize, caterpillars were reared according to the standard protocol until the experimental period. At the onset of the $4^{\text {th }}$ instar, single larvae $(n=20$ per treatment) were transferred to glass containers and assigned to one of the three diet treatments: ad libitum kale (control - K); 15 conspecific eggs and ad libitum kale (treatment $1-\mathrm{K}+\mathrm{E}$ ) and 15 conspecific eggs only (treatment $2-\mathrm{E}$ ). After 24 hours of treatment, kale was supplied ad libitum to all larvae until pupation. We analysed the following parameters: cannibalism rate (number of eggs consumed in the experimental period), larval development time, adult size and fecundity.

Containers were checked twice a day (08:30 and 17:00 h) for pupation and emergence monitoring $(n=20)$. After emergence, butterflies were sacrificed by freezing in order to obtain adult size and fecundity. Posterior left wing $\mathrm{Cu}^{1 \mathrm{a}}$ vein was selected to represent the adult size $(\mathrm{mm})(\mathrm{n}=20)$ (ZagoBraga \& Zucoloto 2004). Afterwards, females were dissected in saline solution. Ovaries were separated and oocytes counted including the terminal ovalled regions from the ovaries $(n=20)$ (Zago-Braga \& Zucoloto 2004). Statistical analysis used the Kruskal-Wallis and the Student-Newman-Keuls tests, with $\alpha=0.05$.

Effect of different nutritional quality foods on cannibalism rates. To verify whether the nutritional state of $A$. monuste orseis caterpillars influences cannibalism rates and kale ingestion, caterpillars were allowed to grow on plastic boxes under the abiotic conditions described above, feeding on kale until $3^{\text {rd }}$ instar. Then, recent $4^{\text {th }}$ instar caterpillars were used in the experiment. Experimental groups consisted of: a) $4^{\text {th }}$ instar caterpillars reared for $24 \mathrm{~h}$ on kale (control, $\mathrm{n}=$ $10)$ and b) $4^{\text {th }}$ instar caterpillars starved for $24 \mathrm{~h}$ (experimental, $\mathrm{n}=10$ ). After these $24 \mathrm{~h}$ treatment period, caterpillars were placed individually (one caterpillar $=$ one replicate) in the center of plastic boxes described above lined with paper towels. One small kale leaf $\left(\sim 7 \mathrm{~cm}^{2}\right)$ and one egg-laying 
with 19 eggs were distributed in the corners of the boxes. Leaves were longitudinally cut, one half was offered to each caterpillar and the other half was dried and weighted, giving an estimate of the initial dry weight of the leaf (Felipe \& Zucoloto, 1993). Caterpillars were allowed to choose for $24 \mathrm{~h}$. The boxes were kept inside an incubator. Two hours after the beginning of the choosing period, the ingestion of eggs and/ or leaf was observed. After the choosing period, the leaf and the egg-laying were removed. The remaining eggs were counted and the leaf mass consumed was measured. The remaining leaf was dried and weighted giving the final dry weight of the food and consequently the daily intake value of dry matter. To calculate the incorporated biomass of each larva, the initial weight of the caterpillars was obtained using the average weight of five individuals, randomly chosen from the group before the experiment. The final weight was represented by the dry weight of the caterpillars at the end of the choice period. All material used to determine the dry weight was maintained in a muffle at $80^{\circ} \mathrm{C}$ for 24 hours (Felipe \& Zucoloto 1993). Data was statistically analyzed by the Mann-Whitney test, with the level of significance set at 5\%.

Feeding behavior in the presence of conspecifics eggs. In order to outline a pattern of $A$. monuste orseis feeding behavior in the presence of conspecific eggs, experimental larvae were raised on the standard kale diet until the experimental period. Newly molted $4^{\text {th }}$ instar caterpillars were transferred to glass containers equipped with a video camera. A leaf disk of kale $\left(19.62 \mathrm{~cm}^{2}\right)$ was placed at the bottom of the container for the caterpillars feeding. Another piece of kale with no conspecific egg was put on the leaf disk of the control group and another piece of kale with 15 conspecific eggs was put on the leaf disk of the experimental group. In each replicate, one caterpillar was put near the piece of kale $(1 \mathrm{~cm})$, with or without eggs. Video recording started as soon as the caterpillar was put on the container.

We recorded the frequency and duration of the following behavioral events: (1) feeding behavior, which consisted of leaf and/or egg ingestion, (2) exploratory behavior, consisting of foraging around the leaf and on laying area and (3) resting behavior, which consisted of remaining motionless. We only analyzed periods longer than 150 seconds, to avoid very short behaviors to would bias frequency mean values to a value that does not represent the commonest durations. Recordings were made with a PANASONIC VHS-C NV A1 video camera and VHS 30 tapes, on SLP speed. Each observation ( $n=10$ per group) lasted approximately 1.5 hour. The data were compared with Mann-Whitney Rank Sum Test (Sigma Stat for Windows, 1994 - Jandel Corporation).

\section{RESULTS}

Sex differences on conspecific ingestion. The cannibalism rates did not differ between $A$. monuste orseis males ( $3.6 \pm$ 2.4 NHC, $\mathrm{n}=25)$ and females $(3.6 \pm 2.9 \mathrm{NHC}, \mathrm{n}=25)$ (mean $\pm \mathrm{SD}, t$-test, $\mathrm{P}>0.05$ ). With respect to adult weight, there was also no significant difference between the control (51.1 \pm 3.6 ,
$59.3 \pm 7.6)$ and experimental $(55.8 \pm 7.5 ; 59.1 \pm 5.6)$ males and females, respectively ( $\mathrm{n}=25$ per sex; means \pm SD, KruskalWallis test, Student-Newman-Keuls, $\mathrm{P}>0.05$ ).

Effect of different nutritional quality foods on performance. Larvae offered kale and conspecific eggs $(\mathrm{K}+\mathrm{E})$ fed significantly less conspecifics than the kale deprived larvae (E); kale deprived caterpillars (E) took longer to pupate and emerge compared to kale satiation group $(\mathrm{K}+\mathrm{E})$ and adult size from treatments significantly differed from control (Table I). Fecundity was negatively influenced by the high cannibalism rates and, more strongly, by kale deprivation (Table I).

Effect of different nutritional quality foods on cannibalism rates. Kale and egg ingestion by $4^{\text {th }}$ instar caterpillars fed with kale $(\mathrm{K})$ and kale deprived (KD) is illustrated in Table II. There was no significant difference in kale ingestion between the groups ( $\mathrm{P}=0.5$, Mann-Whitney Test). A significant difference in egg cannibalism was detected, as $\mathrm{KD}$ caterpillars ingested more eggs than the $\mathrm{K}$ group $(\mathrm{P}=$ 0.03, Mann-Whitney Test). Despite the difference in cannibalism rates between the groups, caterpillars biomass incorporation were similar ( $\mathrm{P}=0.7$, Mann-Whitney Test). In the first two hours of experiment, only one K group caterpillar ingested all the eggs, against 8 caterpillars from the KD group.

Feeding behavior with conspecific eggs. Although not significantly different, caterpillars from both groups spent more time resting, followed by exploratory behavior and feeding (Fig. 1) (Mann-Whitney Test, $\mathrm{P}>0.05$ ). Exploratory behavior significantly differed from the other behaviors within treatments (Mann-Whitney Test, $\mathrm{P}<0.05$ ). There were no significant differences in both frequency and time spent feeding (Mann-Whitney Test, $\mathrm{P}>0.05$ ) (Fig. 2). Cannibalism occurred in all experimental replicates (with conspecific eggs) and only after the exploratory behavior on the egg laying area (data not shown).

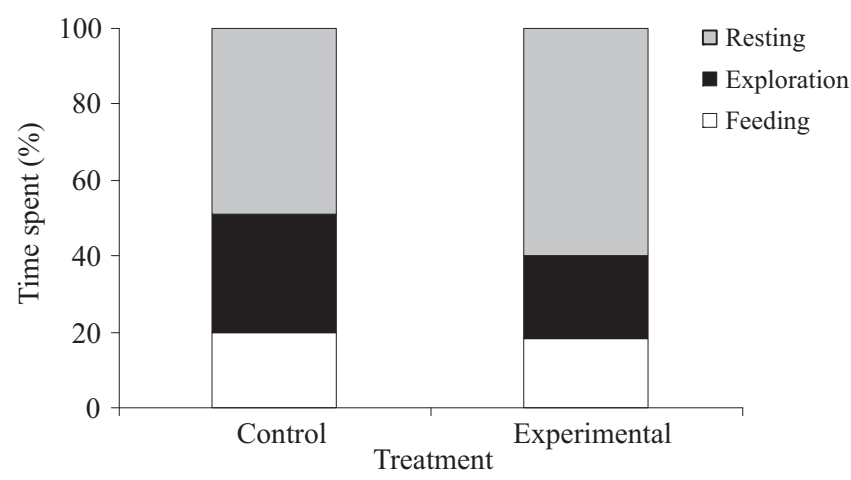

Fig. 1 . Mean activity budgets for the $4^{\text {th }}$ instar $A$. monuste orseis caterpillars observed on kale leaves in the presence (experimental) and absence (control) of conspecific eggs (Mann-Whitney Test, P > 0.05).

Seventy percent of the experimental caterpillars ingested kale during the trials. The time spent ingesting kale was significantly longer on the control $(1112.6 \pm 433.5 \mathrm{~s})$ than on 
Table I. Cannibalism rates and performance traits of $A$. monuste orseis caterpillars fed with: kale only $(K)$, kale +15 A. monuste eggs $(K+E)$ and 15 eggs only $(E)$.

\begin{tabular}{|c|c|c|c|c|c|c|}
\hline \multirow{2}{*}{ Groups } & \multirow{2}{*}{$\begin{array}{c}\text { Number of ingested } \\
\text { eggs }\end{array}$} & \multirow{2}{*}{$\begin{array}{l}\text { Time for pupation } \\
\text { (days) }\end{array}$} & \multirow{2}{*}{$\begin{array}{l}\text { Time for emergency } \\
\text { (days) }\end{array}$} & \multicolumn{2}{|c|}{ Adult size $\left(\mathrm{Cu}^{1 \mathrm{a}}\right)(\mathrm{mm})$} & \multirow{2}{*}{$\begin{array}{c}\text { Fecundity } \\
\left(\mathrm{n}^{\circ} \text { oocytes/female }\right)\end{array}$} \\
\hline & & & & Males & Females & \\
\hline$K$ & - & $9.2 \pm 1.0 \mathrm{ab}$ & $15.9 \pm 0.6 \mathrm{a}$ & $13.1 \pm 0.4 \mathrm{a}$ & $13.2 \pm 0.4 \mathrm{a}$ & $330.0 \pm 40.9 \mathrm{a}$ \\
\hline$K+E$ & $11.1 \pm 5.1 \mathrm{a}$ & $9.0 \pm 0.3 \mathrm{a}$ & $15.2 \pm 0.6 \mathrm{a}$ & $12.1 \pm 0.7 \mathrm{~b}$ & $12.5 \pm 0.8 \mathrm{~b}$ & $262.6 \pm 42.1 \mathrm{~b}$ \\
\hline$E$ & $14.2 \pm 2.1 b$ & $10.0 \pm 0.3 \mathrm{~b}$ & $16.4 \pm 0.5 \mathrm{~b}$ & $12.2 \pm 0.2 \mathrm{~b}$ & $12.5 \pm 0.4 \mathrm{~b}$ & $197.6 \pm 27.0 \mathrm{c}$ \\
\hline
\end{tabular}

$\mathrm{N}=20$ /treament; means \pm SD followed by different letters on the same columm differed significantly (Kruskal-Wallis test, Student-Newman-Keuls, $\mathrm{P}<0.05$ ).

Table II. Kale, egg ingestion and incorporated biomass of $4^{\text {th }}$ instar $A$. monuste orseis caterpillars fed with kale $(K)$ and kale deprived $(K D)$ before the experiment.

\begin{tabular}{|c|c|c|c|}
\hline \multirow{2}{*}{ Groups } & \multicolumn{2}{|c|}{ Ingestion of } & \multirow{2}{*}{$\begin{array}{c}\text { Incorporated } \\
\text { biomass }\end{array}$} \\
\hline & Kale & Eggs & \\
\hline K & $16.7 \pm 10.1 \mathrm{a}$ & $5.7 \pm 9.2 \mathrm{a}$ & $5.9 \pm 3.8 \mathrm{a}$ \\
\hline$K D$ & $19.8 \pm 10.6 \mathrm{a}$ & $15.6 \pm 7.2 \mathrm{~b}$ & $6.0 \pm 3.2 \mathrm{a}$ \\
\hline
\end{tabular}

$\mathrm{N}=10$ /treatment; means \pm SD followed by different letters on the same column differed significantly (Mann-Whitney test, $\mathrm{P}<0.05$ )
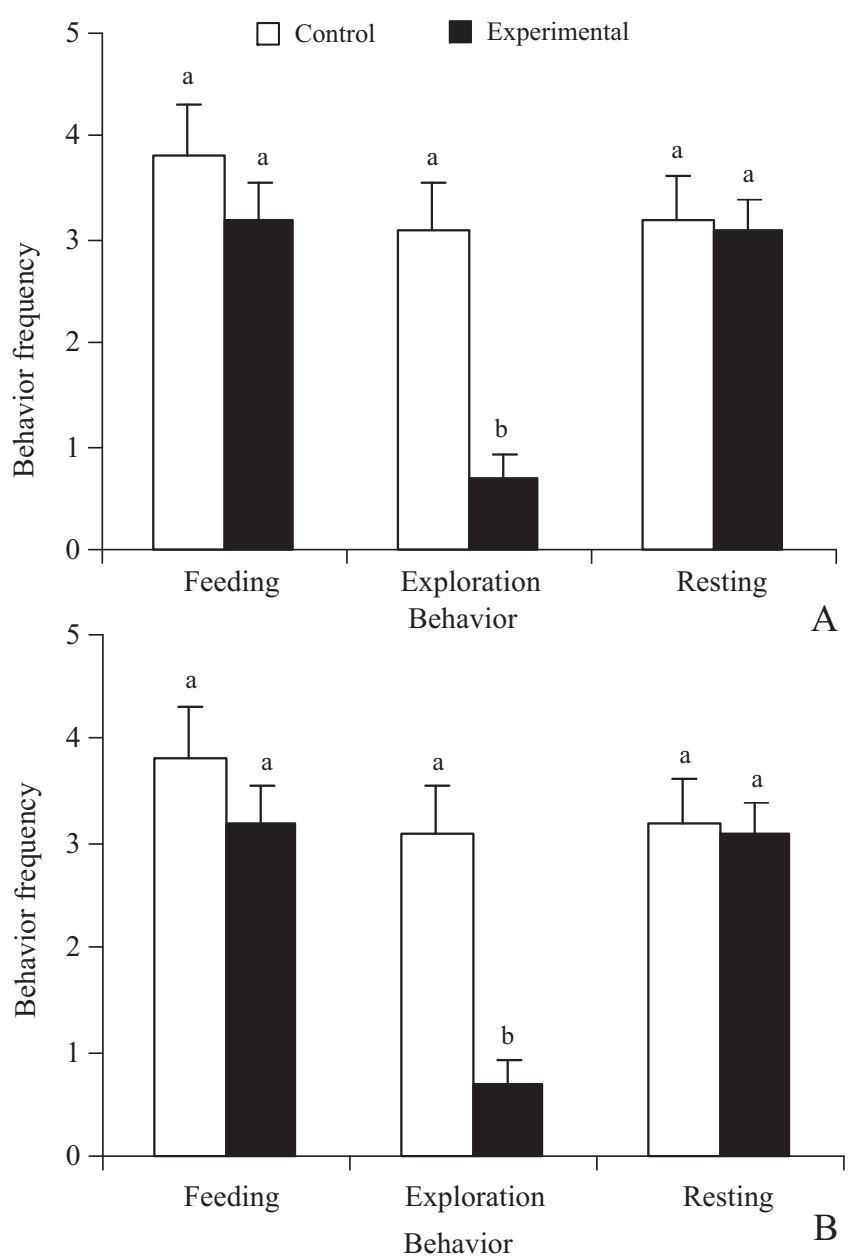

Fig. 2. (A) Duration and (B) frequency of behavioral events (feeding, exploratory and resting) of $4^{\text {th }}$ instar $A$. monuste orseis caterpillars in the presence (experimental) and absence (control) of conspecific eggs. Means \pm SEM followed by different letters between pair columms differed significantly (Mann-Whitney Test, $\mathrm{P}<0.05$ ). the experimental group $(199.6 \pm 199.3 \mathrm{~s})$, as well as the frequency of kale ingestion $(3.0 \pm 1.5$ and $0.6 \pm 0.6$ times, consecutively) (Mann-Whitney Test, $\mathrm{P}<0.05$ ). All the experimental caterpillars took less time ingesting kale (199.6 $\pm 199.3 \mathrm{~s})$ than ingesting eggs $(792.1 \pm 674.5 \mathrm{~s})$ (MannWhitney Test, $\mathrm{P}<0.05$ ).

Behavior switching was frequent in both treatments. During the trials, experimental caterpillars changed their behavior $16.5 \pm 4.4$ times against $20.3 \pm 5.8$ times on the control group. Active (feeding and exploratory behavior, Fig. 3A) and non active (resting behavior, Fig. 3B) periods did not differ significantly between treatments (MannWhitney Test, $\mathrm{P}>0.05$ ).
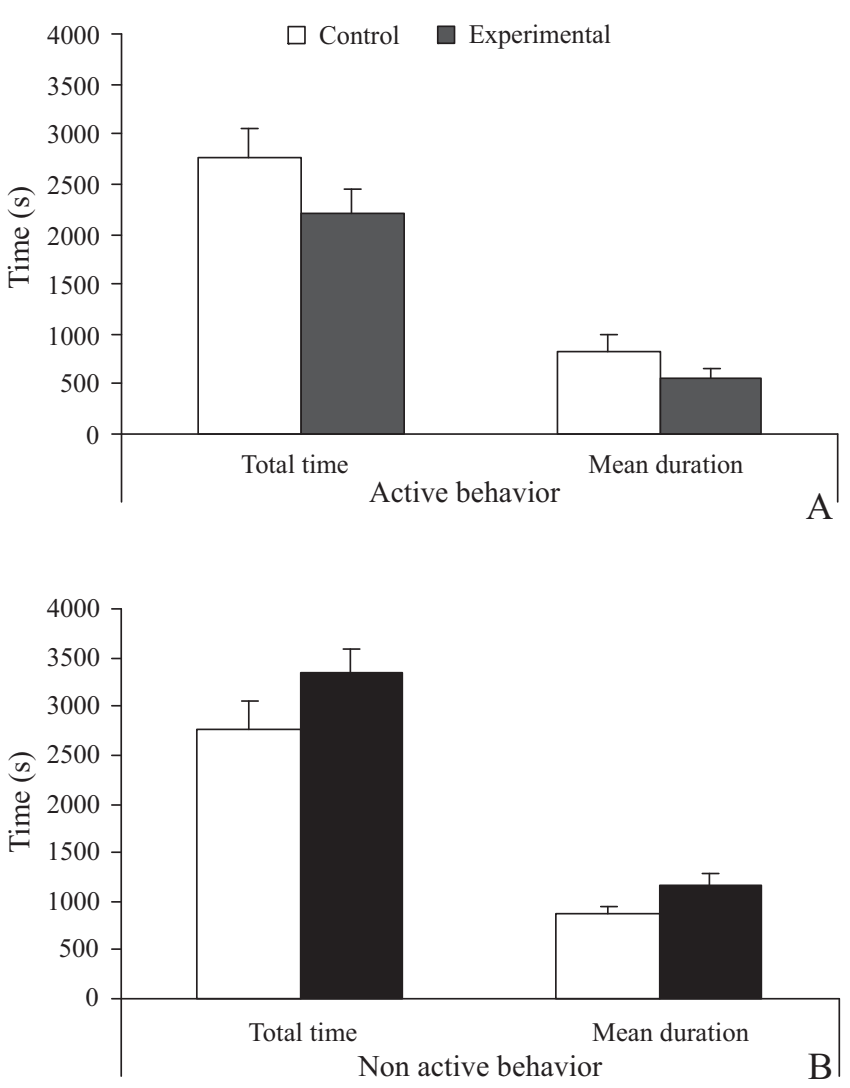

Fig. 3. Total time and mean duration of active (feeding and exploratory) and non active (resting) behaviors of $4^{\text {th }}$ instar $A$. monuste orseis caterpillars in the presence (experimental) and absence (control) of conspecific eggs (means \pm SEM, Mann-Whitney Test, $\mathrm{P}>0.05$ ). 


\section{DISCUSSION}

Studies on species in which the two sexes have the same number of larval stadia have concluded that females attain greater size by ingesting food at a greater rate (Bhat \& Bhattacharya 1978; Telang et al. 2001). However, in our study, A. monuste orseis males and females were not distinguished according to cannibalism rates of NHC.

Although females demand more energy in oocyte production, males also expend energy for sperm production and others substances. Therefore, larva protein demand can be similar irrespective of sex. Besides, the extra load of protein in the larval phase could benefit other adult traits, such as longevity (Boggs \& Freeman 2005). Given that protein reserve for the oocyte formation in $A$. monuste orseis probably occurs earlier in the development, and that the experiments were performed using late instar caterpillars, additional experiments are needed to verify whether at the beggining of the development the cannibalism rates could result in significant differences between males and females.

Cannibalism ranges varied among females and males $(0$ 9 and 0-8 NHC ingested, respectively), which reflects variability in the frequency of the cannibalistic behavior in this species. Such variability is probably related to genetic differences among individuals and to environmental situations to which they are subjected. Genetic differences may turn into behavioral differences, since genes encode enzymes that influence the sensory, nervous and muscular system development of the individual (Krebs \& Davies 1993). This result supports the importance of post-ingestive processing of nutrients in allowing females to accumulate greater nutrient reserves. An important question is: Do females increase consumption on a diet that is protein poor?

The delay on the development of kale deprived caterpillars could be an adaptive strategy to compensate the period that they did not ingest the primary food (Brassicaceae). The kale deprivation could have caused a decrease in the caterpillars biomass gain - caterpillars from $\mathrm{K}$ and $\mathrm{K}+\mathrm{E}$ groups were visually bigger than caterpillars from $\mathrm{E}$ group on the second day of the $4^{\text {th }}$ instar (R. C. Zago, personal observations). The high cannibalism rates of $\mathrm{K}+\mathrm{E}$ and $\mathrm{E}$ groups probably increased the metabolical costs due to digestive and/ or metabolical efficiency adjustments. A diet richer in protein needs a higher proteolitic capacity in order to avoid part of the protein being excreted (Lemos et al. 1992). Egg ingestion could lead to osmotic unbalance, increasing the energetic costs with the excretion of nitrogenate products.

Cannibalism in early instar larvae of $A$. monuste orseis is beneficial (see Barros-Bellanda \& Zucoloto 2001), but can become unprofitable to late instar. The extra load of protein of $\mathrm{K}+\mathrm{E}$ group, in the end of the development, did not increase $A$. monuste orseis adult size. Differences in adult size between groups suggest that kale deprivation is deleterious for the larvae and not the ingestion of eggs per se. The digestion and utilization of all ingested protein becomes impractical to the caterpillars, as a result of protease deficiency and nitrogenated compounds excretion. Besides, amino acid accumulation in the gut may be toxic (Dadd 1985; Zucoloto 1993). Allied to this, older larvae probably do not need protein supplement in this phase of the development.

The biggest damage related to high cannibalism rates was the reduction of the female's fecundity. This result was unexpected, as nitrogen availability does mold female life history, and given extra supply for eggs, thus we would expect females to respond better. However, results suggest that kale deprivation also impairs egg production. Kale satiation seems to be more important to egg development than extra egg protein. Resource deprived caterpillars fed on eggs to redress their nutrient imbalances when the opportunity arose. We have shown that caterpillars remedy their nutritional deficiencies in a relatively short period if given access to a substitutive lacking resource.

In nature, some ovipositional "mistakes" of $A$. monuste orseis females are frequently observed, e.g. large egg clutches (more than 60 eggs per laying), egg-laying on small plants or old leaves and on the stem (Barros-Bellanda \& Zucoloto 2002), which could lead to further immature host deprivation. Egg cannibalism could be adaptive in securing offspring survival when it happens in these situations. Females that make such ovipositional mistakes may have, in some moment of the evolutionary history of the species, facilitated cannibalistic practices and, therefore, stimulated the maintenance of cannibal behavior.

The results show that this species must be adapted to egg cannibalism but not completely, since high cannibalism rates on late instars leads to poor performances. Cannibalistic behavior is advantageous when food sources are of poor quality or scarce and if not practiced in high rates. If this hypothesis is true, it would probably it facilitates the dissemination of cannibal behavior in the species along its evolution.

Ingestion of conspecific eggs did not influence the duration of the feeding events, suggesting no, or only minor, differences in phagostimulatory responses of $A$. monuste orseis caterpillars to this food item. The striking difference between leaf feeding and leaf and conspecifics eggs feeding is the greater frequency of caterpillar's exploratory behavior when there are no eggs available. Caterpillars fed only on leaf took three times longer performing exploratory behavior than did those given conspecific eggs.

The exploratory behavior is important to the perception of predators and is strongly related to the survival of the foraging larvae. Besides, it is a significant aspect of host plant selection. The low frequency of exploratory behavior of the experimental caterpillars results mainly from: 1) the eggs being concentrated in the place of the posture and, in case those eggs were chosen for ingestion, the area to be exploited would be smaller, 2) the nutritive constitution, format and texture of eggs from the same-laying being less different than leaf available parts, which can also be related to the reduction of the exploratory behavior on the environment. The long resting period after the exploratory behavior, in both treat- 
ments (R. C. Zago, pers. obs.), may suggest selection of the resting site. In nature, this selection can increase the immatures survival chances if the chosen place makes them less obvious to predators and parasites.

Resting periods did not differ significantly between treatments. This indicates that behavioral oscillation could be endogenous in this species (Reynolds et al. 1986), rather than being the result of a metabolic feedback. Further investigation is needed to test whether resting and active behavior obeys an endogenous standard.

Longer activity time required to ingest plant food rather than rich protein eggs (Reynolds et al. 1986) and shorter inactivity time required to process food plant rather than eggs (Colasurdo et al. 2007) is probably because, in the plants, nutrients are comparatively dilute. Regular periods of activity and rest may be adaptive in nature (Bernays \& Singer 1998). Any activity, including feeding, is always a severe risk, so that confining essential movements to specific periods may prevent unnecessary activity (Bernays \& Woods 2000).

\section{CONCLUSIONS}

Under natural conditions, food availability is likely to determine the extent to which $A$. monuste orseis caterpillars cannibalize, through the direct influence of their nutritional state. Specific resource deprivation and resulting cannibalism are, therefore, important costs of egg-layings in group and probably also in other systems. Increased exploratory behavior in caterpillars feeding on leaves only interact with their perception of cost-benefit of lower quality food when compared with high protein eggs.

Opportunistic individuals in a population are evolutionarily relevant, especially for the possibility of them to use new resources. Cannibalistic $A$. monuste orseis caterpillars quickly recognized conspecific eggs as food. Hence, cannibalistic behavior seems to be advantageous nutritionally and ecologically to this species' immatures.

\section{ACKNOWLEDGMENTS}

We thank Laércio Massocato for technical assistance, L. G. Elias for the English revision of the manuscript, and financial support from CAPES and CNPq.

\section{REFERENCES}

Agarwala, B. K. \& A. F. G. Dixon. 1992. Laboratory study of cannibalism and interspecific predation in ladybirds. Ecological Entomology 17: 303-309.

Barros-Bellanda, H. C. H. \& F. S. Zucoloto. 2001. Influence of chorion ingestion on the performance of Ascia monuste and its association with cannibalism. Ecological Entomology 26: 557-561.

Barros-Bellanda, H. C. H. \& F. S. Zucoloto. 2002. Effects of intraspecific competition and food deprivation on the immature phase of Ascia monuste orseis (Lepidoptera, Pieridae). Iheringia 92: 93-98.

Barros-Bellanda, H. C. H. \& F. S. Zucoloto. 2003. Importance of larval migration (dispersal) for the survival of Ascia monuste (Godart) (Lepidoptera: Pieridae). Neotropical Entomology 32: 11-17.
Barros-Bellanda, H. C. H. \& F. S. Zucoloto. 2005. Egg cannibalism in Ascia monuste in the field; opportunistic, preferential and very frequent. Journal of Ethology 23: 133-138.

Bernays, E. A. \& M. S. Singer. 1998. A rhythm underlying feeding behavior in a highly polyphagous caterpillar. Physiological Entomology 23: 295-302.

Bernays, E. A. \& H. A. Woods. 2000. Foraging in nature by larvae of Manduca sexta influenced by an endogenous oscillation. Journal of Insect Physiology 46: 825-836.

Bhat, N. S. \& A. K. Bhattacharya. 1978. Consumption and utilization of soybean by Spodoptera litura (Fabricius) at different temperatures. Indian Journal of Entomology 40: 16-25.

Boggs, C. L. 1997. Reproductive allocation from reserves and income in butterfly species with differing adult diets. Ecology 78: 181-191.

Boggs, C. L. \& K. D. Freeman. 2005. Larval food limitations in butterflies:effects on adult resource allocation and fitness. Oecologia 144: 353-361.

Catta-Preta, P. D. \& F. S. Zucoloto. 2003. Oviposition behavior and performance aspects of Ascia monuste (Godart, 1919) (Lepidoptera, Pieridae) on kale (Brassica oleracea var. acephala). Revista Brasileira de Entomologia 47: 169-174.

Colasurdo, N.; A. Dussutour \& E. Despland. 2007. Do food protein and carbohydrate content influence the pattern of feeding and the tendency to explore of forest tent caterpillars? Journal of Insect Physiology 53: 1160-1168.

Dadd, R. H. 1985. Nutrition: organisms, p. 313-389. In: Kerkut G. A. and Gilbert L. I. (eds.). Comprehensive Insect Physiology, Biochemistry and Pharmacology. Oxford, Pergamon Press, 595 p.

Felipe, M. C. \& F. S. Zucoloto. 1993. Estudos de alguns aspectos da alimentação em Ascia monuste Godart (Lepidoptera, Pieridae). Revista Brasileira de Zoologia 10: 333-341.

Fox, L. R. 1975. Cannibalism in natural populations. Annual Review of Ecology and Systematics 6: 87-106.

Joyner, K. \& F. Gould. 1985. Developmental consequences of cannibalism in Heliohtis zea (Lepidoptera: Noctuidae). Annals of the Entomological Society of America 78: 24-28.

Krebs, J. R. \& N. B. Davies (eds.). 1993. An introduction to behavioral ecology. 3rd ed. Oxford/Boston, Blackwell, 386 p.

Lemos, F. J. A.; F. S. Zucoloto \& W. T. Terra. 1992. Enzymological and excretory adaptations of Ceratitis capitata (Diptera: Tephritidae) larvae to high protein and high salt diets. Comparative Biochemistry and Physiology 102A: 775-779.

Nagata, S. \& H. Nagasawa. 2006. Effects of diet-deprivation and physical stimulation on the feeding behaviour of the larvae of the silkworm, Bombyx mori. Journal of Insect Physiology 52: 807-815.

Polis, G. A. 1981. The evolution and dynamics of intraspecific predation. Annual Review of Ecology and Systematics 12: 225-251.

Raubenheimer, D. \& L. Barton-Browne. 2000. Developmental changes in the patterns of feeding in fourth- and fifth-instar Helicoverpa armigera caterpillars. Physiological Entomology 25: 390-399.

Reynolds, S.E., Yeomans, M.R., W.A. Timmins. 1986. The feeding behaviour of caterpillars (Manduca sexta) on tobacco and on artificial diet. Physiological Entomology 11: 39-51.

Simpson, S.J. \& D. Raubenheimer. 2000. The hungry locust. Advances in the Study of Behavior 29: 1-44.

Simpson, S.J. 1982. Patterns in feeding: a behavioural analysis using Locusta migratoria nymphs. Physiological Entomology 7: 325-336.

Simpson, S. J. 1995. Regulation of a meal: chewing insects, p. 137-156. In: R. F. Chapman \& G. De Boer (eds.). Regulatory mechanisms in insect feeding. New York, Chapman and Hall, 398 p.

Slansky, F. \& J. M. Scriber. 1985. Food consumption and utilization, p. 87163. In: G. A. Kerkut \& L. I. Gilbert (eds.). Comprehensive Insect Physiology, Biochemistry and Pharmacology, vol. 4, Oxford. Pergamon Press, 595 p.

Telang, A.; V. Booton; R. F. Chapman \& D. E. Wheeler. 2001. How female caterpillars accumulate their nutrient reserves. Journal of Insect Physiology 47: 1055-1064. 
Timmins, W. A.; K. Bellward; A. J. Stamp \& S. E. Reynolds. 1988. Food intake, conversion efficiency and feeding behaviour of tobacco hornworm caterpillars given artificial diet of varying nutrient and water content. Physiological Entomology 13: 303-314.

Whitman, W. D.; M. S. Blum \& F. Slansky Jr. 1994. Carnivory in phytophagous insect, p. 160-205. In: T. N. Ananthakrishnan (ed.). Functional dynamics of phytophagous insect. New Delhi, Oxford \&
IBH Publishing Co. Pvt. Ltd, 304 p.

Zago-Braga, R. C. \& F. S. Zucoloto. 2004. Studies on eggs and newly hatched caterpillars cannibalism in a wild population of Ascia monuste (Lepidoptera, Pieridae). Revista Brasileira de Entomologia 47: 361-393.

Zucoloto F. S. 1993. Adaptation of Ceratitis capitata population (Diptera, Tephritidae) to an animal protein-based diet. Entomologia Experimentalis et Applicata 67: 119-127. 